Viktoria Ferencsik, Dr.GyulaVarga, Miskolc, Hungary

\title{
ANALYSIS OF SURFACE MICROHARDNESS ON DIAMOND BURNISHED CYLINDRICAL COMPONENTS
}

\begin{abstract}
Cold-plastic forming technologies are one of the most dynamically developing technological processes in these days The main purpose of modern plastic forming is to achieve the shape and size of the designed component by providing minimum environmental loads, while ensuring the proper values of strength and deformation characteristics.These methods include surface strengthening processes, characterized by the introduction of cold forming hardening and residual compressive stress [1]. In this paper, we study the main types of surface consolidation in detail to burnishingof outer cylindrical surfaces.The application of burnishing results in cost reduction in several aspects: cheaper, lower alloyed, lower rigid structural materials can be used as raw materials, abandoned grinding and other fine surface machining, can be replaced by heat treatment operations. In our investigation we used polycrystalline diamond tool with spherical machining surface on C60 hardened steel examining the changing of surface micro-hardness caused by different burnishing parameters.
\end{abstract}

Keywords: burnishing; Factorial Experimental Design; microhardness of burnished layer; number of burnishing passes.

\section{INTRODUCTION}

In the course of the analysis of the structure of the material and its properties, several strengthening mechanisms are known, one of which is forming hardeningoccurred by cold forming. As a consequence of the cold forming is limited to the surface layer, this strengthening mechanism can be exploited to increase the load capacity and, above all, to increase the lifetime by increasing resistance to fatigue strain.Moreover, in the industrial practice the quality requirements of the parts, exposed to fatigue strain, include the value and distribution of residual stressin the subsurface area [2].

To design and execute the experiments, Taguchi type full factorial experimental design method [3-4] was used to create empirical formulas and evaluate the results by a special relationship ratio to determine the parameter setting values that provide the best results within the given technological parameter ranges.

In the present experiments the examined parameters were: burnishing speed $\left(\mathrm{v}_{\mathrm{b}}\right)$, feed rate (f), burnishing force $\left(\mathrm{F}_{\mathrm{b}}\right)$ and the number of passes (i). The latter means how many times the tool passes along linearly on the rotating workpiece surface.

Measuring of the surface micro-hardness of the specimens were executed with Wilson Instruments Tukon 2100B measuring equipment in Vickers hardness. 


\section{SURFACE BURNISHING}

Finishing operations of high precision and low roughness working surfaces of shafts are grinding or polishing, lapping. These operations significantly reduce the surface roughness, but essentially only slightly modify the properties of the surface layer. For occasional substitution of these relatively low productivity and costly chip removal processes, burnishing is used on outer cylindrical surface. The practical implementation of it can be seen in Fig 1.

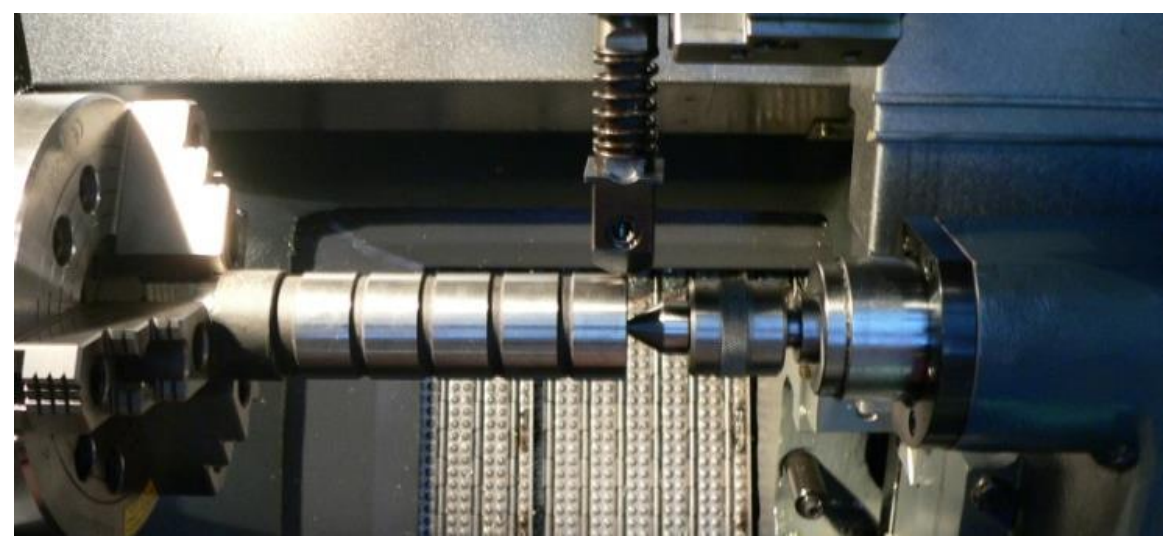

Figure 1 - Burnishing in CNC lathe

During the experiments, a CNC lathe with flatbed by firm OPTIMUM type OPTIturn S600 was used which is located in the workshop of Institute of Manufacturing Science at University of Miskolc. The tool tip was PCD (polycrystalline diamond) with $3.5 \mathrm{~mm}$ radius and the kinematic viscosity of the manual dosed oil was $70 \mathrm{~mm}^{2} / \mathrm{s}$.

\section{EXPERIMENTAL CONDITIONS}

\subsection{Burnishing parameters}

A number of test results are available in the literature for the burnishing of certain heat-treated (hardness) workpieces with different technological parameters [5-9]. Summarized the factors determining the micro-hardness of the surface layer, according to the above mentioned studies, the following pie chart can be drawn:

From these parameters the burnishing force, feed rate, and speed were choosen setting with two values of number of passes. The latter does not belong to the factors because the experimental design, such as the representation of the results will be too difficult and less obvious with four factors. 


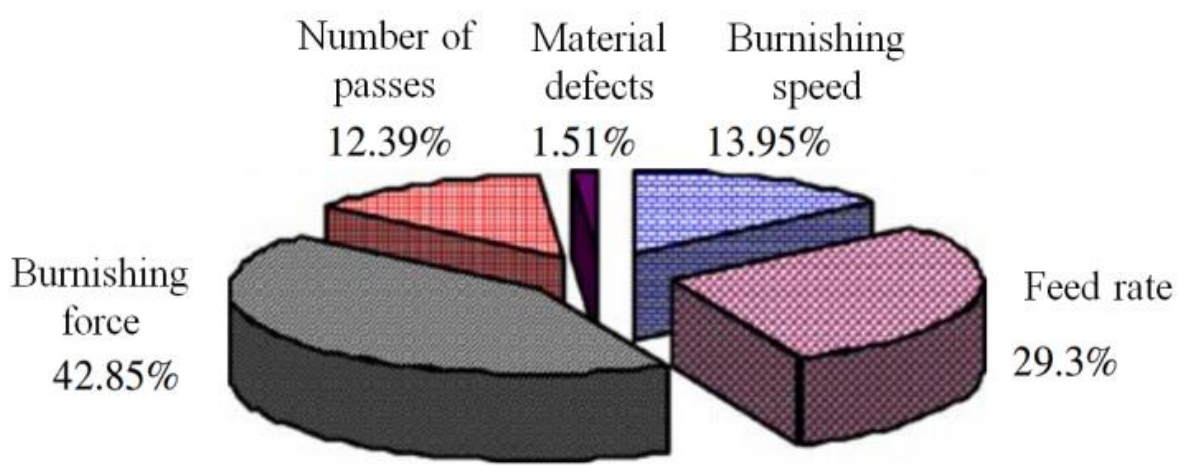

Figure 2 - Parameters affecting surface micro-hardness [8]

In the matrix of the Taguchi type full factorial experimental design (Table 1) we can see these parametersin natural dimensions and their transformed values Table 1 - Applied burnishing parameters

\begin{tabular}{|c|c|c|c|c|c|c|}
\hline \multirow{2}{*}{$\begin{array}{c}\text { Sign of } \\
\text { specimen }\end{array}$} & \multicolumn{3}{|c|}{ Parameters of burnishing } & \multicolumn{3}{c|}{ Transformed parameters } \\
\cline { 2 - 7 } & $\mathrm{F}_{\mathrm{b}}[\mathrm{N}]$ & $\mathrm{f}[\mathrm{mm} / \mathrm{rev}]$ & $\mathrm{vb}_{\mathrm{b}}[\mathrm{m} / \mathrm{min}]$ & $\mathrm{X}_{1}$ & $\mathrm{X}_{2}$ & $\mathrm{X}_{3}$ \\
\hline 1 & 50 & 0.05 & 40 & -1 & -1 & -1 \\
\hline 2 & 100 & 0.05 & 40 & +1 & -1 & -1 \\
\hline 3 & 50 & 0.1 & 40 & -1 & +1 & -1 \\
\hline 4 & 100 & 0.1 & 40 & +1 & +1 & -1 \\
\hline 5 & 50 & 0.05 & 80 & -1 & -1 & +1 \\
\hline 6 & 100 & 0.05 & 80 & +1 & -1 & +1 \\
\hline 7 & 50 & 0.1 & 80 & -1 & +1 & +1 \\
\hline 8 & 100 & 0.1 & 80 & +1 & +1 & +1 \\
\hline
\end{tabular}

\subsection{Measuring of surface micro-hardness}

The apparatus (Wilson Instruments Tukon 2100B) also measures Vickers hardness, which has the same principle as all hardness measurements, is to examine how a material is subject to plastic deformation by using a standard force. During the measurement, a $136^{\circ}$ diamond pulley is pressed with a specific force, $10 \mathrm{~N}$ in our experiments for 10 seconds on the surface to be measured. In the course of the evaluation, using a CCD camera, weigh the traces of the imprint and the average of the two is calculated by the device own software calculating the impression surface [10]. Fig 3 illustrates the measurement and a Vickers test imprint on the workpiece surface. 


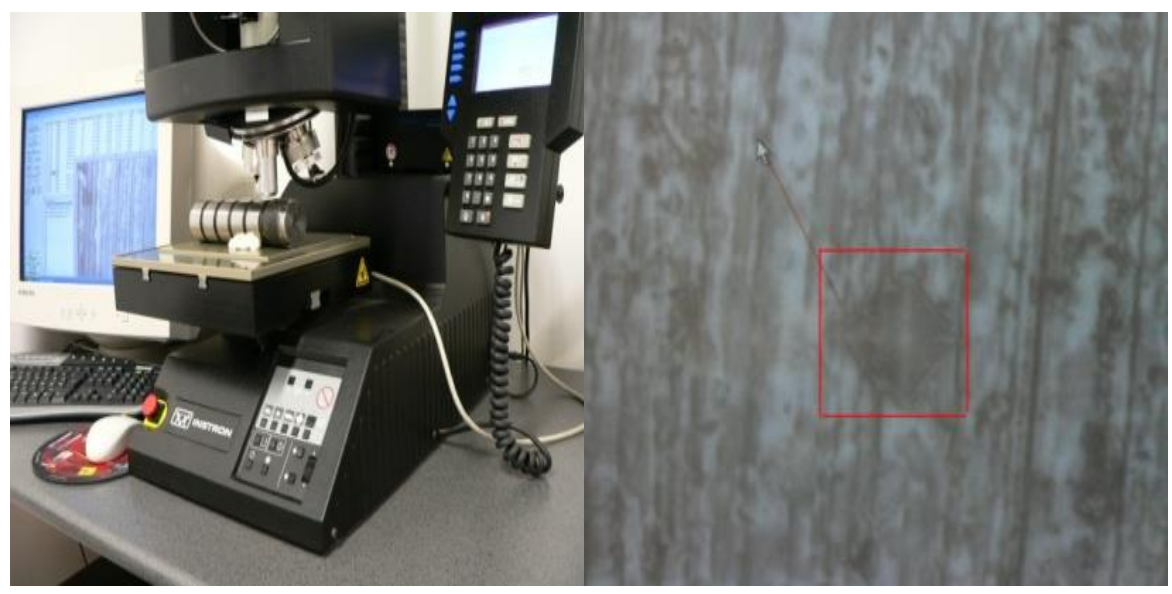

Figure 3 - Measurement process

In order to capture the most accurate values, we carried out control measurements both on the workpiece surface and on a control block calibrating the device.

\section{RESULTS AND EVALUATIONS}

For evaluation of measured data an improvement ratio was introduced, which is shown in formula (1):

$$
P_{H V}=\frac{m v_{b}-m v_{g}}{H V_{g}}=100 \%
$$

where: $\rho_{\mathrm{HV}}$ Dimensionless improvement ratio of the surface microhardness,

$\mathrm{HV}_{\mathrm{b}}$ Hardness of the burnished surface,

$\mathrm{HV}_{\mathrm{g}}$ Hardness of the grinded surface.

The larger the value of $\rho_{\mathrm{HV}}$, the greater is the improvement due to burnishing.

In some cases decrease in hardness was experienced, the reason of it will be investigated

Measured data and the improvement ratios of surfacesmicro-hardness, calculated by formula (1), in the case of setting 1 and 3number of passes, summarized in Table 2. 
Table 2 - Measured and calculated results

\begin{tabular}{|c|c|c|c|c|c|c|}
\hline \multirow{2}{*}{$\begin{array}{c}\text { Sign of } \\
\text { specimen }\end{array}$} & \multicolumn{2}{|c|}{$\begin{array}{l}\mathrm{HV} \\
\mathrm{i}=1\end{array}$} & \multirow{2}{*}{$\rho_{\mathrm{HV}}[\%]$} & \multicolumn{2}{|c|}{$\begin{array}{l}\mathrm{HV} \\
\mathrm{i}=3\end{array}$} & \multirow{2}{*}{$\rho_{\mathrm{HV}}[\%]$} \\
\hline & $\begin{array}{c}\text { after } \\
\text { grinding }\end{array}$ & $\begin{array}{c}\text { after } \\
\text { burnishing }\end{array}$ & & $\begin{array}{c}\text { after } \\
\text { grinding }\end{array}$ & $\begin{array}{c}\text { after } \\
\text { burnishing }\end{array}$ & \\
\hline 1 & \multirow{5}{*}{882.4} & 985.5 & 11.68 & \multirow{2}{*}{883} & 1018.5 & 15.35 \\
\hline 2 & & 914 & 3.58 & & 961.5 & 8.89 \\
\hline 3 & & 977 & 10.72 & \multirow{5}{*}{874.6} & 986 & 12.74 \\
\hline 4 & & 1059 & 20.01 & & 909 & 3.93 \\
\hline 5 & & 1024 & 16.05 & & 906.5 & 3.65 \\
\hline 6 & \multirow{3}{*}{883} & 860 & -2.60 & & 865.5 & -1.04 \\
\hline 7 & & 832 & -5.78 & & 1042.5 & 19.19 \\
\hline 8 & & 854.5 & -3.33 & 846 & 991.5 & 17.19 \\
\hline
\end{tabular}

We created empirical formulas (2-3) from the calculated values, further calculations and demonstrations (Fig. 7-8) were created by "MathCAD 16.0" software.

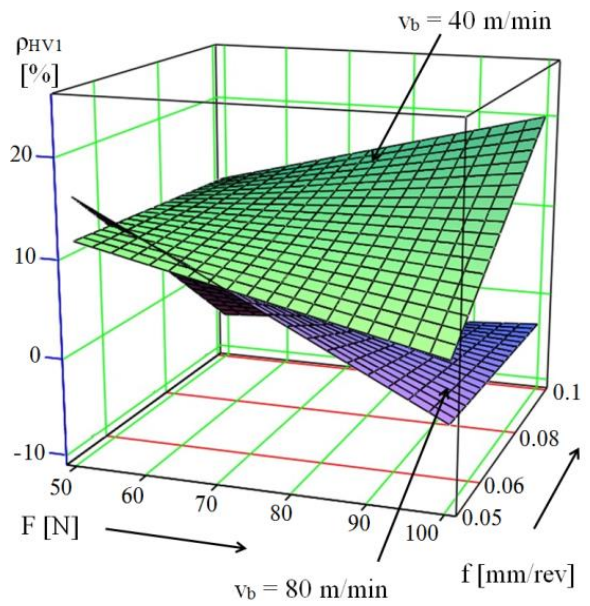

Figure 4 - Changing of surface micro-hardness in the case of $i=1$

$$
\begin{aligned}
& \rho_{H V_{1}}=-1.37-0.225 \cdot F_{b}+124.6 \cdot f+0.998 \cdot v_{b}+5.472 \cdot F_{b} \cdot f- \\
& \quad-7.13 \cdot 10^{-3} \cdot F_{b} \cdot v_{b}-12.29 \cdot f \cdot v_{b}+0.037 \cdot F_{b} \cdot f \cdot v_{b} \\
& \rho_{H V_{3}}=48.65-0.017 \cdot F_{b}-267.4 \times f-0.665 \cdot v_{b}-2.956 \cdot F_{b} \cdot f- \\
& \quad-1.635 \cdot 10^{-3} \cdot F_{b} \cdot v_{b}+6.555 \cdot f \cdot v_{b}+0.05 \cdot F_{b} \cdot f \cdot v_{b}
\end{aligned}
$$




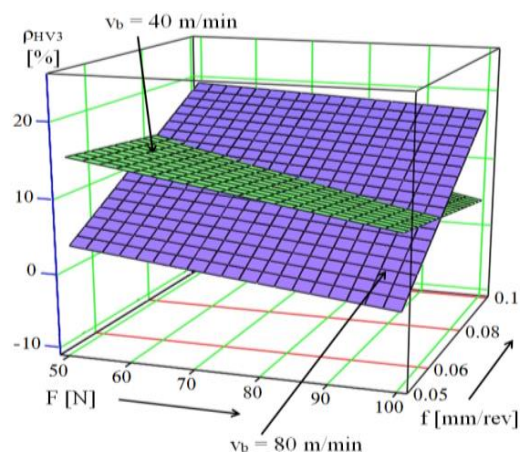

Figure 5 - Changing of surface micro-hardness in the case of $i=3$

\section{SUMMARY}

The paper contains diamond burnishing experiments on hardened steel with its measurement and evaluation results. The purpose of this study was to determine how the choosen burnishing parameters affect the change of micro-hardness. The experiments and the evaluation of the measurement results were performed by using the Taguchi type full factorial experimental design method. According to the measured, calculated and illustrated results the following conclusions have been drawn:

- Among the examined parameters, the effect of feed rate is the most dominant and it has a strong interaction with the burnishing speed

- Parameters that resulted the largest and thus the most favorable surface micro-hardness were follows:

$\mathrm{F}=50 \mathrm{~N} ; \quad \mathrm{v}_{\mathrm{c}}=80 \mathrm{~m} / \mathrm{min} ; \quad \mathrm{f}=0.10 \mathrm{~mm} / \mathrm{rev} ; \quad \mathrm{i}=3$

\section{ACKNOWLEDGEMENTS}

"The described study was carried out as part of the EFOP-3.6.1-16-00011 "Younger and Renewing University - Innovative Knowledge City - institutional development of the University of Miskolc aiming at intelligent specialisation" project implemented in the framework of the Szechenyi 2020 program. The realization of this project is supported by the European Union, co-financed by the European Social Fund."

"Project no. NKFI-125117 has been implemented with the support provided from the National Research, Development and Innovation Fund of Hungary, financed under the K_17 funding scheme."

References: 1. M. Tisza, A. Balogh, J. Schaffer: Mechanical Technologies, Miskolc, (2007) p:73-74. (in Hungarian). 2. V. Mertinger, J. Sólyom, M. Benke: MonoCap optics for X-ray diffraction tests, Journal of Materials Testers, (2012), pp.: 60-64. 3. G. Taguchi: System of experiment design, 1. Experimental 
design, UNIPUB, Kraus International Publications, White Plains, New York, (1987) ISBN 0-52791621-8. 4. L. Fridrik: Chosen chapters from the topics of experimental design of production engineering, MüszakiKönyvkiadó, Budapest, 1987 (In Hungarian). 5. L. Bálint, L. Gribovszki (1975). The basics of machine engineering technology, Miskolc, p: 418-442. (in Hungarian). 6. V. Ferencsik: Examination of 3D Surface Roughness of diamond Burnished Surfaces, Scientific Student Paper (2013) p.: 37. 7. W. Brostow, K. Czechowski, W. Polowski, P. Rusek, D. Toboła, I. Wronska: Slide diamond burnishing of tool steels with adhesive coatings and diffusion layers, Material Research Innovations, (2013) pp.: 269-277. 8. T.A. El-Taweel, M.H. El-Axir: Analysis and optimization of the ball burnishing process through the Taguchi technique, International Journel Advertising of Manufacture Technology 41, (2009) pp.: 301-310. 9. G. Varga.: Effects of Technological Parameters on the Surface Texture of Burnished Surfaces, Key Engineering Materials, Volume 581: Precision Machining VII, 2013, pp.: 403408. 10. Wilson Instruments Tukon 2100B Vickers/Knoop Hardness Tester User Guide.

\title{
Вікторія Ференчик, Дюла Варга, Мішкольц, Угорщина
}

\section{АНАЛІЗ ПОВЕРХНЕВОЇ МІКРОТВЕРДОСТІ НА ЦИЛІНДРИЧНИХ ДЕТАЛЯХ ПІСЛЯ АЛМАЗНОГО ВИГЛАДЖУВАННЯ}

\begin{abstract}
Анотація: Технології холодного пластичного формування $\epsilon$ одними з тих, які найбільш динамічно розвиваються у намі дні Основною метою сучасного пластичного формування $\epsilon$ досягнення форми $i$ розмірів проектованого компонента шляхом забезпечення мінімальних екологічних навантажень, при забезпеченні належних значень міџності та деформачійної стійкості. Ці методи включають в себе процеси поверхневого зміцнення, що характеризуються введенням холодного поверхневого зміцнення $і$ залишковими напругами стиснення. $B$ даній роботі ми вивчаємо основні типи ущільнення поверхні детально до ущільнення зовнішніх ииліндричних поверхонь. Застосування спалювання призводить до зниження вартості в декількох аспектах: дешевші, низьколеговані, нижчі тверді конструкиійні матеріали можуть бути використані як сировина, відмова від шліфування та іншої тонкої обробки поверхні, може бути замінена термічною обробкою. 3 аналізу структури матеріалу і його властивостей відомо кілька зміцьнюючих механізмів, одним з яких є змічнення, щзо виникає при холодній деформації. Внаслідок того, що холодне деформування обмежене поверхневим шаром, ией підсилюючий механізм може бути використаний для збільшення опору зовнішнім навантаженням $i$, перш за все, для збільшення терміну служби за рахунок збільшення опору втомної деформації. Крім того, в промисловій практиці, вимоги до якості деталей, схильних до втомних напружень, відносяться величина і розподіл залишкових напружень в приповерхневій зоні. Мета иього дослідження полягала в тому, щоб визначити, як вибрані параметри зміинення впливають на зміну мікротвердості. Експерименти $i$ оцінка результатів вимірювань проводились 3 використанням методу планування повного факторного експерименту типу Тагучі. На підставі виміряних, розрахованих і проілюстрованих результатів були зроблені наступні висновки: серед розглянутих параметрів вплив швидкості подачі є найбільш домінуючим, $і$ воно тісно пов'язане зі швидкістю ущільнення. Параметри, які привели до найбільшої $і$, отже, найбільш сприятливою мікротвердості поверхні, були наступними: сила притиску 50Н, швидкість $80 \mathrm{м} /$ хв, подача $0,1 \mathrm{мм} /$ об.
\end{abstract}

Ключові слова: вигладжування; планування факторного експерименту; мікротвердість полірованого шару; кількість вигладжувальних проходів. 